\title{
Efficient production of a-acetolactate by whole cell catalytic transformation of fermentation-derived pyruvate
}

\author{
Robin Dorau, Lin Chen, Jianming Liu, Peter Ruhdal Jensen ${ }^{*}$ and Christian Solem * (1)
}

\begin{abstract}
Background: Diacetyl provides the buttery aroma in products such as butter and margarine. It can be made via a harsh set of chemical reactions from sugarcane bagasse, however, in dairy products it is normally formed spontaneously from a-acetolactate, a compound generated by selected lactic acid bacteria in the starter culture used. Due to its bacteriostatic properties, it is difficult to achieve high levels of diacetyl by fermentation. Here we present a novel strategy for producing diacetyl based on whole-cell catalysis, which bypasses the toxic effects of diacetyl.

Results: By expressing a robust a-acetolactate synthase (ALS) in a metabolically optimized Lactococcus lactis strain we obtained a whole-cell biocatalyst that efficiently converted pyruvate into a-acetolactate. After process optimization, we achieved a titer for a-acetolactate of $172 \pm 2 \mathrm{mM}$. Subsequently we used a two-stage production setup, where pyruvate was produced by an engineered L. lactis strain and subsequently used as the substrate for the biocatalyst. Using this approach, $122 \pm 5 \mathrm{mM}$ and $113 \pm 3 \mathrm{mM}$ a-acetolactate could be made from glucose or lactose in dairy waste, respectively. The whole-cell biocatalyst was robust and fully active in crude fermentation broth containing pyruvate.
\end{abstract}

Conclusions: An efficient approach for converting sugar into a-acetolactate, via pyruvate, was developed and tested successfully. Due to the anaerobic conditions used for the biotransformation, little diacetyl was generated, and this allowed for efficient biotransformation of pyruvate into a-acetolactate, with the highest titers reported to date. The use of a two-step procedure for producing a-acetolactate, where non-toxic pyruvate first is formed, and subsequently converted into a-acetolactate, also simplified the process optimization. We conclude that whole cell catalysis is suitable for converting lactose in dairy waste into a-acetolactate, which favors resource utilization.

Keywords: Biocatalysis, Lactococcus lactis, Metabolic engineering, Process engineering, Diacetyl, Lactose

\section{Background}

Diacetyl, a generally recognized as safe (GRAS) compound with a pleasant buttery flavor, is widely used in the food industry $[1,2]$. Diacetyl can be made by chemical or biological means. The chemical approach involves high temperature treatment of sugarcane bagasse under oxygen limiting conditions, and through a series of radical

*Correspondence: perj@food.dtu.dk; chso@food.dtu.dk National Food Institute, Technical University of Denmark, 2800 Kgs. Lyngby, Denmark reactions diacetyl is formed [3]. Despite the harsh conditions used, the diacetyl recovered in this way is classified as natural.

In traditional dairy products, such as butter, diacetyl arises due to the activity of lactic acid bacteria (LAB). Different LAB, such as Lactococcus lactis subsp. lactis biovar diacetylactis, Leuconostoc spp. [4] and various Lactobacillus spp. [5, 6] are able to generate diacetyl, or more precisely its precursor $\alpha$-acetolactate, when citric acid is present. By metabolizing citric acid, the $L A B$ achieve a growth advantage, since acid stress is relieved

(C) The Author(s) 2019. This article is licensed under a Creative Commons Attribution 4.0 International License, which permits use, sharing, adaptation, distribution and reproduction in any medium or format, as long as you give appropriate credit to the original author(s) and the source, provide a link to the Creative Commons licence, and indicate if changes were made. The images or other third party material in this article are included in the article's Creative Commons licence, unless indicated otherwise in a credit line to the material. If material is not included in the article's Creative Commons licence and your intended use is not permitted by statutory regulation or exceeds the permitted use, you will need to obtain permission directly from the copyright holder. To view a copy of this licence, visit http://creativeco mmons.org/licenses/by/4.0/. The Creative Commons Public Domain Dedication waiver (http://creativecommons.org/publicdomain/ zero/1.0/) applies to the data made available in this article, unless otherwise stated in a credit line to the data. 
to some extent [7]. In Lactococcus lactis subsp. lactis biovar diacetylactis citrate is transported into the cell via the citrate permease (CitP) and cleaved by citrate lyase (CL) into acetate and oxaloacetate. The latter is subsequently decarboxylated by oxaloacetate decarboxylase (OD) into pyruvate. Thus, the consumption of citrate increases the pyruvate pool, without increasing the NADH production in the cell. The excess pyruvate is subsequently consumed via the acetoin pathway, comprised of $\alpha$-acetolactate synthase (ALS) and $\alpha$-acetolactate decarboxylase (ALD) (Fig. 1). $\alpha$-Acetolactate, the intermediate in this pathway, is inherently unstable and can either be enzymatically converted into acetoin or undergo spontaneous decarboxylation to diacetyl under aerobic condition [4, 8-11]. As a result, $\alpha$-acetolactate is mainly transformed into acetoin. However, small amounts of diacetyl can also form when oxygen is present. It has been found that the presence of metal ions accelerate the chemical conversion of $\alpha$-acetolactate into diacetyl, which can be used for industrial diacetyl production $[4,12]$. Even though diacetyl is a very potent flavor molecule there are some advantages of using $\alpha$-acetolactate instead, since diacetyl is highly volatile, which complicates its use in food products. To avoid this, $\alpha$-acetolactate can be added to the products directly and diacetyl is then formed slowly when the product gets in contact with oxygen. Thereby a long-lasting taste is obtained, and high initial concentrations of diacetyl are avoided [21].

Metabolic engineering has been used to improve diacetyl formation [12-19]. Hugenholtz et al. overexpressed NADH-oxidase (NOX) in an ALD deficient strain and managed to generate $5.7 \mathrm{mM} \alpha$-acetolactate and $1.6 \mathrm{mM}$ diacetyl using resting cells [14]. We have previously reported the highest diacetyl titer ever achieved for lactic acid bacteria, $95 \mathrm{mM}$, which was attained using a metabolically rewired strain of L. lactis, blocked in all major catabolic pathways except for the one leading to $\alpha$-acetolactate and growing under respiratory conditions [12]. The $\alpha$-acetolactate accumulated in the fermentation broth was subsequently converted into diacetyl using a metal ion catalyst. The chemical unstability of $\alpha$-acetolactate, however, also resulted in diacetyl accumulation in the course of the fermentation, which ultimately affected growth and limited the production of $\alpha$-acetolactate. Previously, it has been found that $10 \mathrm{mM}$ of diacetyl completely inhibits growth of $L$. lactis $[12,14]$, and it was demonstrated that the cytoplasmic NOX was one of the enzymes that is hampered the most by diacetyl [14]. Diacetyl affects other enzymes as well, which may explain its strong antimicrobial activity [20]. In the earlier work, we relied on respiration to regenerate $\mathrm{NAD}^{+}$and successfully generated large amounts of $\alpha$-acetolactate

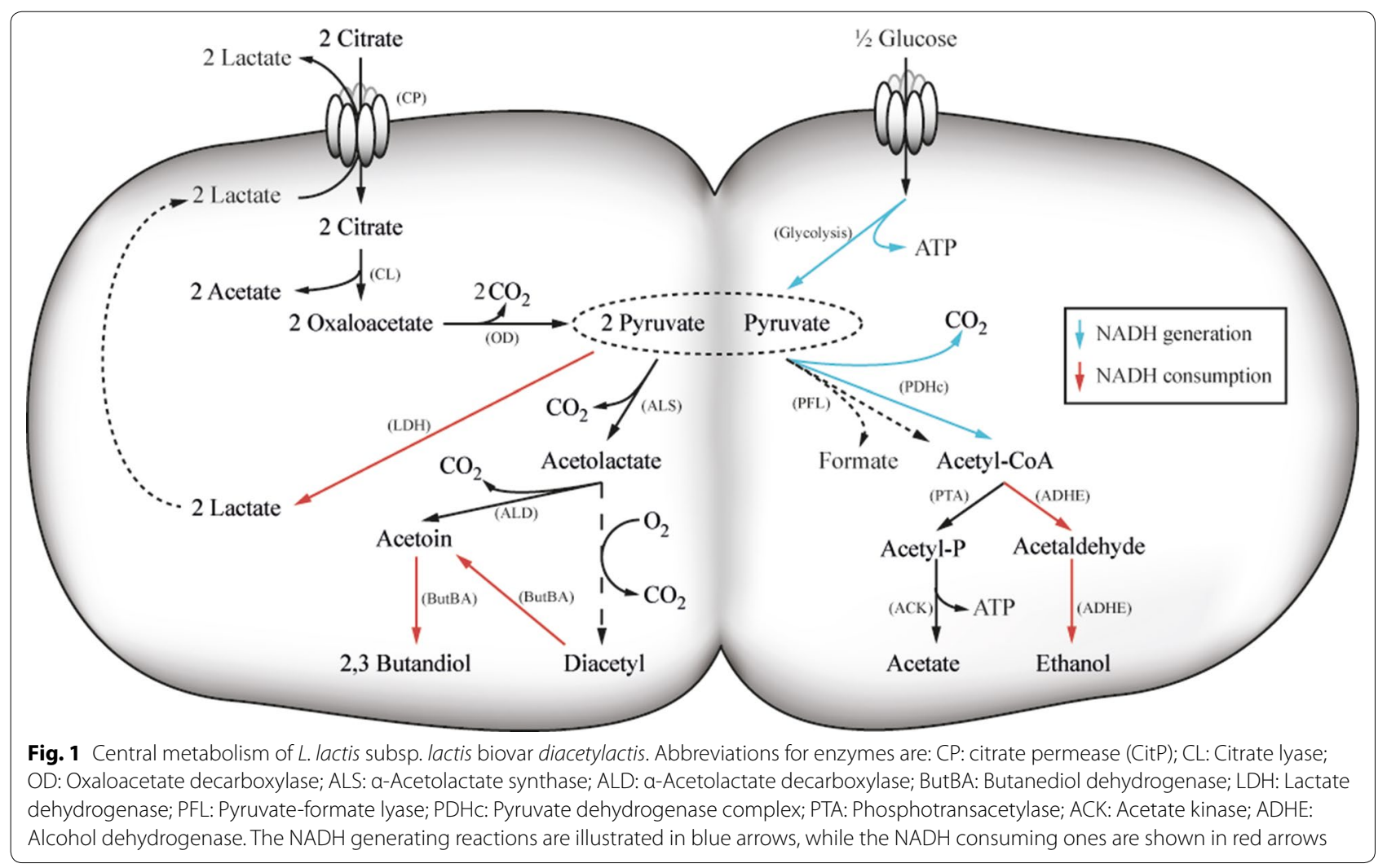


and diacetyl [12], however, there are some drawbacks to this approach. Firstly, slow diacetyl accumulation took place during the fermentation, probably due to the presence of oxygen, which catalyzes the decomposition of $\alpha$-acetolactate. Second, hemin adds additional costs to the fermentation process.

There are few reports describing the use of whole-cell biocatalysis for producing $\alpha$-acetolactate from glucose or pyruvate [21,22]. Using resting cells of an L. lactis strain with a deleted ALD (aldB) and an overexpressed NOX (noxE), $5.7 \mathrm{mM} \alpha$-acetolactate was obtained [14]. In the patent literature it has been claimed that higher $\alpha$-acetolactate titers can be obtained from pyruvate using whole cells or cell lysates of L. lactis [21, 22]. It thus appears that production of $\alpha$-acetolactate by using whole-cell biocatalysis is possible, however, the existing processes do not seem to be commercially attractive due to low titers. It is however plausible that $\alpha$-acetolactate production using a whole-cell catalysis process can be further improved, e.g. by optimizing the $\alpha$-acetolactate synthase and by optimizing the production parameters.
Recently, we developed a pyruvate producing L. lactis strain, which can accumulate up to $49.7 \mathrm{~g} / \mathrm{l}(564 \mathrm{mM})$ pyruvate from glucose or lactose under aerobic condition (Suo et al. manuscript submitted). Under anaerobic conditions, $\alpha$-acetolactate or pyruvate formation directly from sugar is normally not feasible as the $\mathrm{NADH}$ produced during glycolysis needs to be reoxidized, and this usually happens through either lactate formation or mixed-acid formation [23, 24]. Under aerobic conditions, however, NOX or respiration can reconstitute the NADH/NAD ${ }^{+}$balance, thus allowing the cells to grow [12, 23, 24] and produce $\alpha$-acetolactate, but with the drawback that inhibitory amounts of diacetyl can be formed during the fermentation. Here we explore a different strategy for producing $\alpha$-acetolactate, which is based on whole cell catalyzed transformation of pyruvate (Fig. 2). We start out by constructing a suitable chassis based on L. lac$t i s$, then test the effectiveness of different $\alpha$-acetolactate synthase enzymes and finally optimize various parameters for the cell catalyst.

\section{Presented approach: Pyruvate-fermentation and biocatalysis for producing $\alpha$-acetolactate}

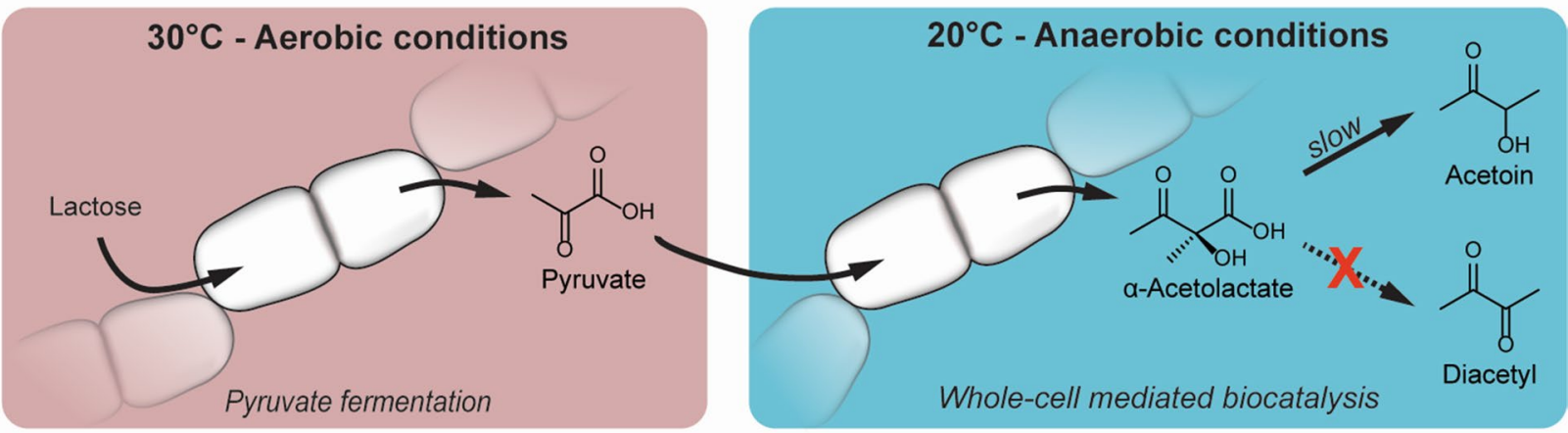

Previous approaches: $\alpha$-Acetolactate-fermentation

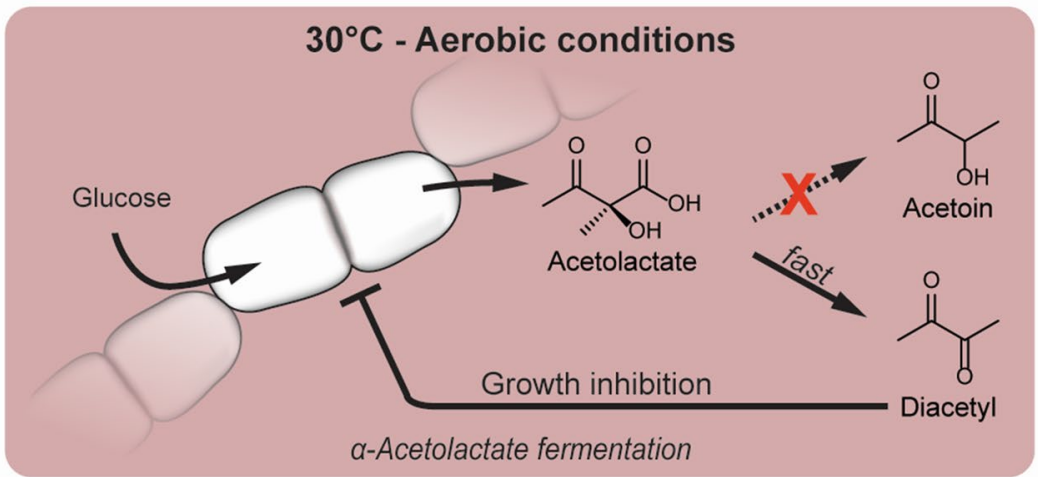

Benefits of using biocatalysis: is Avoid side products $\hbar$ High $\alpha$-acetolactate titers 厺 Cheap carbon sources

Fig. 2 Overview of the whole cell catalyzed approach for producing a-acetolactate, which is explored in this study (upper row). Previous approaches for producing a-acetolactate directly via fermentation (lower row). Shifting the reaction environment from aerobiosis to anaerobiosis is advantageous for accumulating a-acetolactate and higher titers can be reached 


\section{Results}

\section{Strain construction for whole cell biocatalysis}

The inherent instability of $\alpha$-acetolactate, causing it to decompose to growth inhibiting diacetyl in the presence of oxygen, makes it a challenge to achieve high titers by aerated fermentation. We envisioned that using a production strategy based on whole cell based biocatalysis might be a superior approach, e.g. by using pyruvate as a substrate. Pyruvate can be obtained via fermentation using cheap carbon sources as described elsewhere (Suo et al., manuscript submitted). Diacetyl can easily be prepared from the resulting $\alpha$-acetolactate by subsequent aeration, a reaction that can be further accelerated by metal-ion catalysts. In order to be efficient, the whole-cell catalyst should possess a high $\alpha$-acetolactate synthase activity, and any genes encoding enzyme activities that could interfere with $\alpha$-acetolactate production should be inactivated. L. lactis subsp. cremoris MG1363 is a well-characterized model strain, which we decided to use in this study. Starting from the previously described strain CS4525 (MG1363 $\Delta l d h, \Delta l d h B \Delta l d h X \Delta p t a \Delta a d h E$ $\triangle b u t B A \triangle a l d B$, pCS4268) [12], we derived ll-cat01 (MG1363 $\Delta l d h B \quad \Delta l d h X \quad \Delta p t a \triangle a d h E \triangle b u t B A \Delta a l d B$ ) by concurrent plasmid curing and selection for anaerobic growth. In this strain the chromosomal $l d h$ had been restored after a recombination event with the plasmid encoded $l d h$ gene. ll-cat01 satisfied the requirements to be used as a chassis for our whole cell catalyst.

\section{a-Acetolactate can be obtained from pyruvate using an $L$. lactis whole cell biocatalyst}

As proof of principle, we applied ll-cat01 in a solution containing $500 \mathrm{mM}$ pyruvate buffered with citrate $(100 \mathrm{mM})$ at different $\mathrm{pH}$ values in $1 \mathrm{ml}$ volume. We assayed the $\alpha$-acetolactate concentration during the first $5 \mathrm{~h}$ of the reaction using a colorimetric assay. This assay allows for determination of the acetoin concentration after converting $\alpha$-acetolactate to acetoin under acidic conditions. As $\alpha$-acetolactate decarboxylase had been knocked out and there is no other cofactor independent metabolic pathway, we expected pyruvate to be converted exclusively into $\alpha$-acetolactate. We did observe formation of $\alpha$-acetolactate, however, only at $\mathrm{pH}$ above 5 (Fig. 3). At pH 4.5 the catalyst appeared inactive, and no product was formed. At higher $\mathrm{pH} \alpha$-acetolactate was formed, and the maximum titer was seen after $5 \mathrm{~h}$ at pH $5.5(20.6 \pm 0.3 \mathrm{mM})$. Since $\mathrm{pH}$ increases when two equivalents of acidic pyruvate $(\mathrm{pKa}=2.5)$ are converted into one equivalent of the less acidic $\alpha$-acetolactate $(\mathrm{pKa}=3.45)$, it is likely that higher titers could have been obtained if the $\mathrm{pH}$ was controlled better, and this would explain the lower activity of the cell catalyst at $\mathrm{pH}$ 6.0.

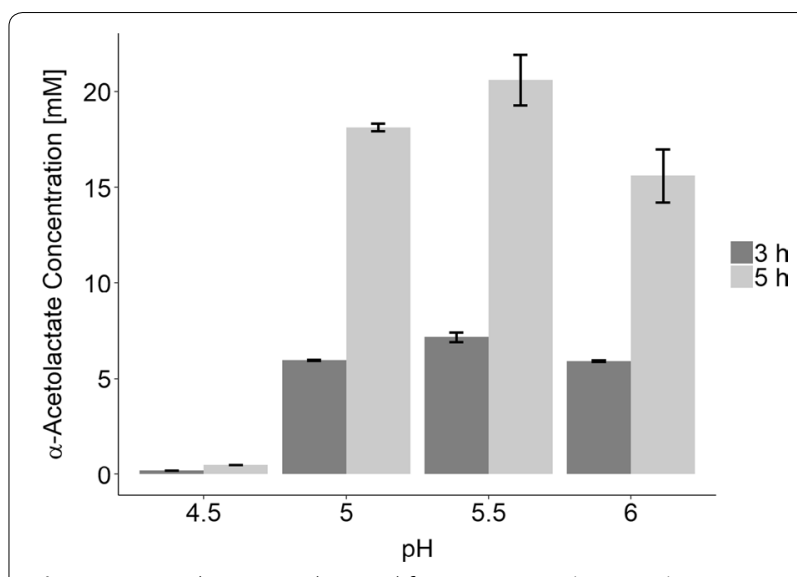

Fig. 3 a-Acetolactate is obtained from pyruvate $(500 \mathrm{mM})$ using

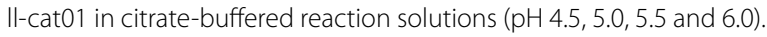
Concentrations after $3 \mathrm{~h}$ (dark) and $5 \mathrm{~h}$ (light) are shown

\section{Optimization of the biocatalysis process with different a-acetolactate synthases}

The catalytic effeciency of $\alpha$-acetolactate synthase (ALS) is likely to limit the efficiency of the biocatalysis process. Therefore, enhancing the ALS activity is important for optimizing the biocatalytic process and can be done in different ways, e.g. by overexpressing ALS or lowering the $K_{m}$ by expressing heterologous ALS. We decided to overexpress three different ALS enzymes, the native ALS from Lactococcus lactis (ll-ALS), ALS from Bacillus licheniformis WX-02 (bl-ALS) [25] and ALS from Enterococcus faecalis (ef-ALS) [26], where the latter two have been reported to be robust enzymes with high affininty towards pyruvate (Additional file 1: Table S2). The three enzymes were overexpressed individually in the strain ll-cat01 using the same expression cassette, resulting in strains RD04 (ll-ALS), RD05 (bl-ALS) and RD06 (efALS). As a negative control the empty plasmid (pLC0) was transformed into ll-cat01, resulting in RD03.

The optimal $\mathrm{pH}$ for the four strains: RD03-RD06 containing the four different plasmids: pLC0, pLC17, pLC02, pLC01 was determined using $\mathrm{pH}$-monitoring, which was initially established and verified with ll-cat01 using different $\mathrm{pH}$ at the beginning of the reaction (see Additional file 1: Figure S1). All four strains showed "S"shapes, when monitoring $\mathrm{pH}$ over time, indicating functional expression of the enzymes (Fig. 4a). Moreover, the curves differed significantly from each other: While the shape for RD03 and RD05 was rather flat, the shape for RD04 and RD06 showed a very sharp increase in activity early in the experiment. The difference in shape indicates altered reaction rates, which becomes more obvious when plotting the $\Delta \mathrm{pH}$ versus either time or $\mathrm{pH}$ (Fig. $4 \mathrm{~b}$, c). The peaks in the corresponding curves shows the time 


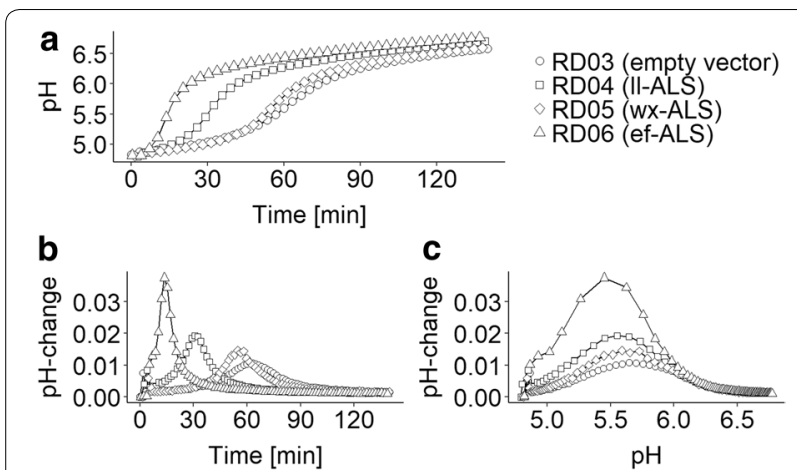

Fig. 4 Comparison of the four strains RD03-RD06, derived from the same host II-cat01 containing the plasmids pLCO, pLC17, $\mathrm{pLC02}$, pLC01, as biocatalysts for the conversion of pyruvate to a-acetolactate. RD03-RD06 were incubated in an unbuffered solution containing $0.5 \mathrm{M}$ pyruvate at $\mathrm{pH} 4.6$ at $\mathrm{OD}_{600}=1.0$. $\mathrm{RD} 03$ contains the empty cloning vector as negative control (circles). RD04-RD06 contain plasmids over-expressing different a-acetolactate synthase enzymes from L. lactis (II-ALS) (squares), B. licheniformis WX-02 (bl-ALS) (diamonds) and E. faecalis (ef-ALS) (triangels). A: $\mathrm{pH}$-profile ( $\mathrm{pH}$ against time [min]). B: delta-pH as indicator for the catalytic activity. C: delta-pH against $\mathrm{pH}$. Because of the generally small errors, the error bars are not indicated here

or $\mathrm{pH}$ when the consumption rate of pyruvate is highest and the magnitude gives an indication of the overall maximum activity. The data indicates that RD06 performs best under the given condition, followed by RD04, RD05 and RD03. This trend was confirmed in small scale biotransformations, where the $\mathrm{pH}$ was kept constant using a buffer (Additional file 1: Figure S2). Surprisingly, all four strains showed a very similar optimal $\mathrm{pH}$ between 5.5 and 5.6 (Fig. 4c). We chose RD06 for subsequent scale-up experiments because of its superior performance.

\section{Low temperature and high cell density are beneficial for $\boldsymbol{a}$-acetolactate accumulation}

It is well known that $\alpha$-acetolactate spontaneously decarboxylates in aqueous solution and forms acetoin or diacetyl depending on the absence or presence of oxygen, respectively. The process can be accelerated in acidic environments and proceeds faster at high temperature $[10,11]$. To determine the optimal temperature for $\alpha$-acetolactate accumulation using RD06, the stability of $\alpha$-acetolactate under different conditions was evaluated. The initial concentration of $\alpha$-acetolactate was determined to be approximately $83 \mathrm{mM}$. Generally, it was observed that $\alpha$-acetolactate mainly decarboxylates into acetoin, but other unknown side products are formed as well, especially at high temperatures. Figure 5 shows that increasing temperatures and prolonged reaction time are suboptimal for the accumulation of $\alpha$-acetolactate. At $50{ }^{\circ} \mathrm{C}$, already after $6 \mathrm{~h}$, only $19.1 \pm 1.4 \mathrm{mM}$ of the initial

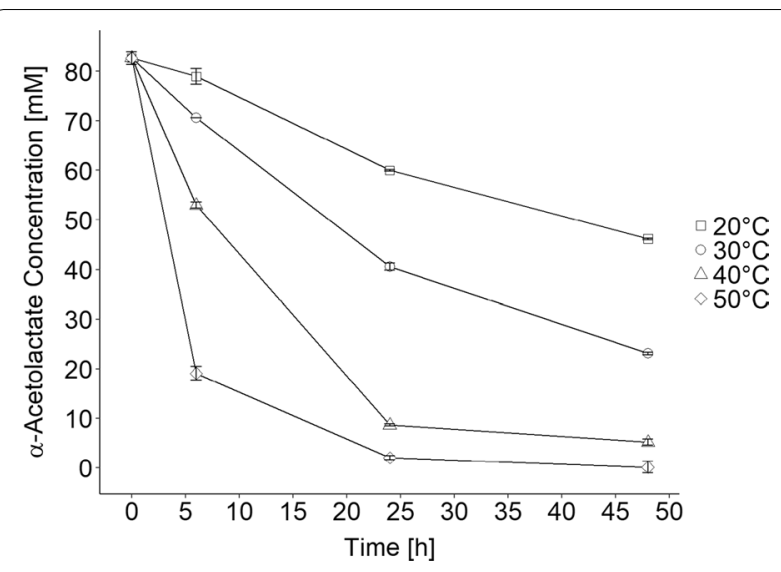

Fig. 5 Stability of a-acetolactate at different temperatures $\left(20^{\circ} \mathrm{C}\right.$ (squares), $30^{\circ} \mathrm{C}$ (circles), $40^{\circ} \mathrm{C}$ (triangles) and $50^{\circ} \mathrm{C}$ (diamonds)) and in the presence of $500 \mathrm{mM}$ pyruvate and $100 \mathrm{mM}$ citrate at pH 5.5 . a-Acetolactate decarboxylates to mainly form acetoin but also other side products

$83 \mathrm{mM} \alpha$-acetolactate remained $(23 \pm 2 \%)$ and after $24 \mathrm{~h}$ at $40{ }^{\circ} \mathrm{C}$ and $50{ }^{\circ} \mathrm{C}$ only $8.6 \pm 0.2 \mathrm{mM}(10.4 \pm 0.1 \%)$ and $2.0 \pm 0.4 \mathrm{mM}(2.5 \pm 0.4 \%)$ remained, respectively. When comparing the lower temperatures, $20^{\circ} \mathrm{C}$ was found to be suitable since at $30{ }^{\circ} \mathrm{C}$ after $24 \mathrm{~h}$ already more than half of the $\alpha$-acetolactate had been degraded. We decided to apply the biocatalyst at $20^{\circ} \mathrm{C}$ at laboratory scale in order to stabilize $\alpha$-acetolactate and increase the biocatalyst concentration to compensate for decreased reaction rates. We found a linear correlation between cell density and $\alpha$-acetolactate production (see Additional file 1: Figure S3) and concluded that higher cell densities indeed can be applied to compensate for lower reaction rates caused by lower temperatures. To validate this hypothesis, we determined the $\alpha$-acetolactate formation rate $[\mathrm{mM} / \mathrm{min}]$ of RD06 at different temperatures from $15{ }^{\circ} \mathrm{C}$ to $30{ }^{\circ} \mathrm{C}$ (Additional file 1: Figure S4). In this temperature range a nearly linear correlation was observed and we demonstrated that increased cell density can compensate for the lower $\alpha$-acetolactate formation rate when using lower temperatures (e.g. $20{ }^{\circ} \mathrm{C}$ ). Higher cell densities might also compensate for increased $\alpha$-acetolactate degradation at higher temperatures when shorter reaction times are applied.

\section{Biotransformations under optimized conditions}

As mentioned above, $\alpha$-acetolactate rapidly decomposes into diacetyl in the presence of oxygen. Therefore, the following laboratory-scale biotransformations were carried out under anaerobic conditions. For the bioconversion we applied the optimal conditions established above $\left(\mathrm{pH} 5.5,20^{\circ} \mathrm{C}\right)$ and the most efficient catalyst (RD06). The consumption of pyruvate as well as the production 
of $\alpha$-acetolactate and acetoin were followed over a period of $72 \mathrm{~h}$ (Fig. 6). The biotransformation reached it optimal state after $30 \mathrm{~h}$, when the $\alpha$-acetolactate concentration was at a maximum $(172 \pm 2 \mathrm{mM})$ and $472 \pm 40 \mathrm{mM}$ pyruvate had been consumed. We found that longer reaction times resulted in a loss of $\alpha$-acetolactate because of spontaneous decarboxylation into acetoin. At the maximal $\alpha$-acetolactate concentration the yield from pyruvate was $73 \pm 9 \%$ ( $\mathrm{mol} \alpha$-acetolactate $/ 0.5^{*} \mathrm{~mol}$ pyruvate consumed), and only smaller amounts of acetoin $(23 \pm 1 \mathrm{mM})$ and unknown side products were observed using HPLC (see Additional file 1: Figures S6-S8). Furthermore, during the biotransformation we observed a slight decrease in cell density, which might explain the decreased $\alpha$-acetolactate formation rate in the later stages of the reaction (Additional file 1: Figure S9).

\section{a-Acetolactate production using a dairy side-stream as feedstock}

We have demonstrated that our cell catalyst can transform a buffered solution of pure pyruvate efficiently into $\alpha$-acetolactate, however, we do not know if the cell catalyst is active in spent fermentation broth containing pyruvate. Since we recently have generated $L$. lactis strains able to ferment either glucose or lactose into pyruvate, we decided to investigate this. The two strains FS1072 and FS1080, able to metabolize glucose or lactose respectively were used for the purpose. Two pyruvate solutions containing $393 \pm 30 \mathrm{mM}$ pyruvate (GM17) and $380 \pm 6 \mathrm{mM}$ pyruvate (residual whey permeate) were produced (Phase I, Figs. 7 and 8). The pyruvate titers obtained using these strains were somewhat lower than previously observed, but since the objective here was to demonstrate the

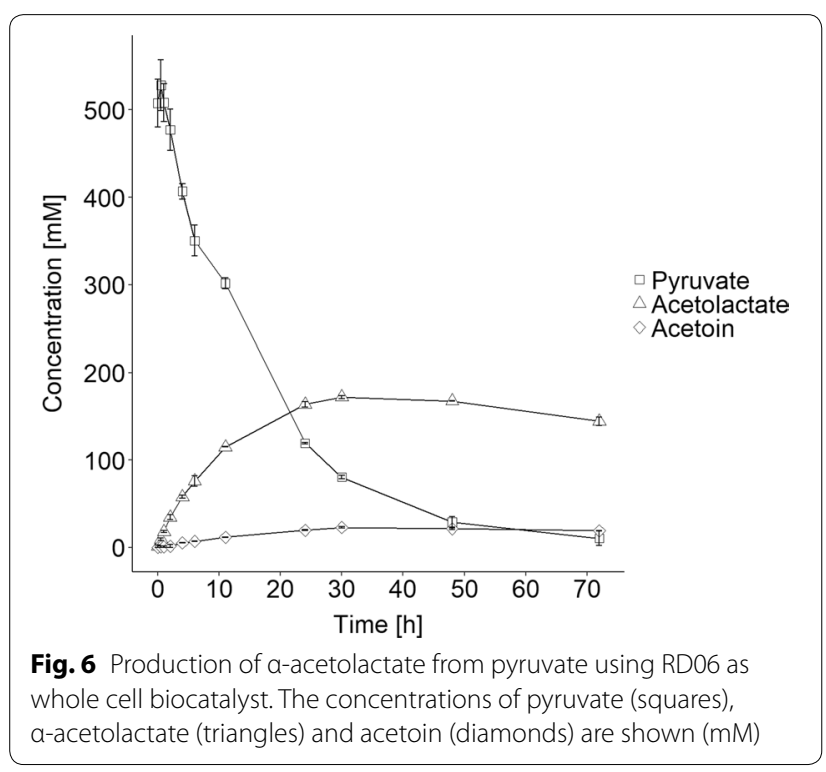

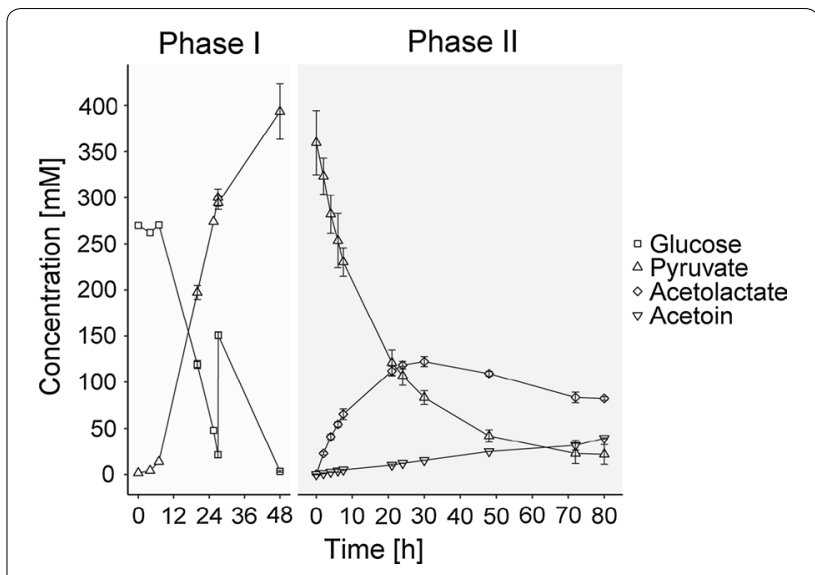

Fig. 7 Production of a-acetolactate from glucose via pyruvate. Glucose is fermented using FS1072 in M17 broth and pyruvate is obtained (Phase I). After $74 \mathrm{~h}$ FS1072 was removed from the broth and RD06 was applied as whole cell biocatalyst for converting pyruvate into a-acetolactate (Phase II). The concentrations of glucose (squares), pyruvate (triangles), a-acetolactate (diamonds) and acetoin (inverted triangle) are shown [mM]. Lactate and acetate were observed at different levels after phase I $(81 \pm 8 \mathrm{mM}$ and $38 \pm 8 \mathrm{mM}$, respectively), but they remained constant during phase $I I$ and are therefore not shown

functionality of the cell catalyst, we did not pursue optimization of the pyruvate fermentation, which is described elsewhere (Suo et al. manuscript submitted). Indeed, the cell catalyst turned out to be highly active in the presence of the various components present in the rich media used, which demonstrates the robustness

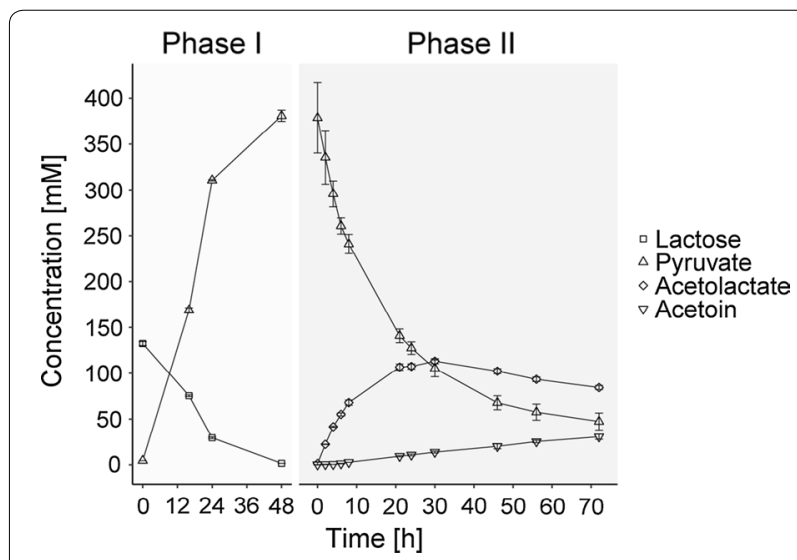

Fig. 8 Production of a-acetolactate from lactose via pyruvate. Lactose is fermented using FS1080 in RWP and pyruvate is obtained (Phase I). After $48 \mathrm{~h}$ FS1080 was removed from the broth and RD06 was applied for converting pyruvate into a-acetolactate (Phase II). The concentrations of Lactose (squares), pyruvate (triangles), a-acetolactate (diamonds) and acetoin (inverted triangle) are shown $(\mathrm{mM})$. Lactate and acetate were observed at different levels after phase I ( $68 \pm 4 \mathrm{mM}$ and $31 \pm 4 \mathrm{mM}$, respectively), but they remained constant during phase II and are therefore not shown 
of the biocatalyst. The $\alpha$-acetolactate concentrations reached maxima after $30 \mathrm{~h}$ in phase II with $122 \pm 5 \mathrm{mM}$ or $113 \pm 3 \mathrm{mM}$ in GM17 or RWP, respectively. After $30 \mathrm{~h}$, $15.2 \pm 0.2$ and $13.8 \pm 0.9 \mathrm{mM}$ acetoin had been formed in GM17 and RWP, respectively. However, in contrast to when using pure pyruvate, a nearly linear increase in acetoin concentration was observed for both reactions after $30 \mathrm{~h}$. This indicates that $\alpha$-acetolactate stability is compromised in GM17 and RWP, as the increase in acetoin concentration is directly ascribed to the decomposition of $\alpha$-acetolactate. To summarize, $\alpha$-acetolactate yield from pyruvate was $80 \pm 3 \%(\mathrm{~mol} \alpha$-acetolactate $/ 0.5 \% \mathrm{~mol}$ pyruvate consumed) for the reaction in GM17-broth and $76 \pm 11 \% \quad$ (mol $\alpha$-acetolactate $/ 0.5 \% \mathrm{~mol}$ pyruvate consumed) in RWP-broth. Compared to the biotransformation using pure pyruvate, the yields were similar. The overall yield from glucose or lactose were $44 \pm 6 \%$ (mol $\alpha$-acetolactate/mol glucose consumed) or $43 \pm 14 \%$ (mol $\alpha$-acetolactate/2*mol lactose consumed), which are both rather low, because of the non-optimized pyruvate fermentations.

\section{Discussion}

We have demonstrated that biocatalysis is applicable for producing high titers of $\alpha$-acetolactate from pyruvate, either pure or fermentation derived. Due to its unstable nature, it is difficult to obtain high titers of $\alpha$-acetolactate by fermentation, and the best results this far have been realized using aerated conditions [12, 27]. Using anaerobic conditions in combination with a cell catalyst, in this study, we managed to reach $172 \pm 2 \mathrm{mM}$ of $\alpha$-acetolactate.

Normally, when producing so-called starter distillates, diacetyl in fermented broth is concentrated by steam distillation to prepare a potent flavoring agent, and the remaining liquid constitutes waste. In this study, we achieved higher concentrations of $\alpha$-acetolactate, which can be quantitatively converted to diacetyl, e.g. using $\mathrm{Fe}^{3+}$-ions and the obtained product potentially could be added directly to food products.

We find that, for all cell catalysts tested, the optimal $\mathrm{pH}$ is around 5.5. This is a little surprising since slightly different $\mathrm{pH}$-optima have been reported previously for the different ALS enzymes used (Additional file 1: Table S2). It is likely that the low $\mathrm{K}_{\mathrm{m}}$ of ef-ALS is responsible for the superior performance of RD06. As all three enzymes were overexpressed from the same expression cassette, similar expression values are expected, but potentially bl-ALS is expressed less efficiently due to the lower phylogenetic relationship between lactococci and bacilli explaining the inferior performance of RD05. In future work, metabolic, protein or process engineering is likely to further enhance the efficiency and applicability of the presented process. As indicated above, biotransformation at higher temperatures such as $30{ }^{\circ} \mathrm{C}$ with increased cell density (e.g. $\mathrm{OD}_{600}=10.0$ ) would accelerate the conversion considerably. However, at the same time, $\alpha$-acetolactate would be less stable and side products would form more rapidly. Nevertheless, a shorter biotransformation under those conditions might be desired in some industrial settings. For other cell catalysts, permeabilization was beneficial for improving efficiency [28, 29]. Unfortunately, our attempts to permeabilize the whole-cell biocatalyst using ethanol resulted in decreased reaction rates and reduced $\alpha$-acetolactate yields (data not shown). It is possible that ALS requires a reduced environment for full functionality as present within intact cells. Another aspect of commercialization is the reusability of the cells, because it is expensive to produce biomass. Reusability would ease large scale applications of the presented technology. Surprisingly, when cells, which had been used for a biotransformation in pyruvate solution, were reused under the same reaction conditions, the formation of a different product was observed, which we have not identified yet. Further attempts for reusing the cells are ongoing.

\section{Conclusion}

In this study, we have demonstrated the production of $\alpha$-acetolactate from pyruvate $(172 \pm 2 \mathrm{mM})$ and a dairy derived waste stream $(113 \pm 3 \mathrm{mM})$. The reported product titers are exceeding previously published results. In our experiments, we used bioreactors for the biotransformation of pyruvate into $\alpha$-acetolactate, which makes a subsequent upscaling easier because the conditions can be more directly transferred to larger vessels. The presented process further provides a solution for the recycling of a dairy waste stream into a desired food ingredient.

\section{Methods \\ Bacterial strains and DNA techniques}

ll-cat01 (MG1363 $\Delta l d h B \Delta l d h X \quad \Delta p t a \Delta a d h E \triangle b u t B A$ $\triangle a l d B)$ is a plasmid free strain derived from $L$. lactis MG1363 [30]. Gene deletions were achieved using the method developed by Solem et al. [31]. The vector pLC0 is a size-reduced derivative of pTD6 [32] lacking the gus A gene. The $\alpha$-acetolactate-synthase genes from Enterococcus faecalis ATCC 29212 (ef-ALS), Bacillus licheniformis WX-02 (bl-ALS) [25], and Lactococcus lactis MG1363 (ll-ALS) were cloned into pLC0 resulting in the plasmids pLC01, pLC02, and pLC17, respectively. To overexpress these genes, they were put under the control of the strong constitutive promoter P8 [33].

FS1072 (Table 1) was constructed based on the strain CS4363 [32] by deleting the als gene. To make the strain able to use lactose as carbon source, the plasmid 
Table 1 Bacterial strains and plasmids used in this study

\begin{tabular}{|c|c|c|}
\hline Designation & Genotype or description & Reference \\
\hline \multicolumn{3}{|l|}{ L. lactis strains } \\
\hline MG1363 & Plasmid free L. lactis strain & {$[30]$} \\
\hline FS1072 & MG1363 $\Delta^{3} / d h \Delta$ pta $\Delta a d h E \Delta a l s$ & (Suo et al.) \\
\hline FS1080 & FS1072 containing the pLP712 plasmid & (Suo et al.) \\
\hline II-cat01 & MG1363 $\triangle l d h B \Delta l d h X \Delta p t a \triangle a d h E \triangle b u t B A \triangle a l d B$ & This work \\
\hline RD03 & pLC0 in II-cat01 & This work \\
\hline RD04 & pLC17 in II-cat01 & This work \\
\hline RD05 & pLC02 in II-cat01 & This work \\
\hline RD06 & pLC01 in II-cat01 & This work \\
\hline \multicolumn{3}{|l|}{ Plasmids } \\
\hline pLP712 & Plasmid from L. lactis NCDO712 encoding lactose utilization gene custer & {$[30]$} \\
\hline pLCO & pTD6 derived plasmid & This work \\
\hline pLC01 & pLC0 inserted with the als gene from Enterococcus faecalis ATCC 29212 (ef-ALS) & This work \\
\hline pLC02 & pLC0 inserted with the als gene from Bacillus licheniformis WX-02 (bl-ALS) & This work \\
\hline $\mathrm{pLC} 17$ & pLC0 inserted with the als gene from Lactococcus lactis MG1363 (II-ALS) & This work \\
\hline
\end{tabular}

pLP712 was extracted from the strain NCDO712 and transformed into the strain FS1072, resulting in the strain FS1080 (Table 1) (Suo et al. manuscript submitted).

\section{Construction of the plasmids pLC0, pLC01, pLC02, and pLC17}

PCR products $p L C O-L$ amplified from the plasmid pTD6 with the primers $p T D-C F 1$ and $p T D-C R 1$ (see Additional file 1: Table S1) were circularized using T4 DNA ligase after phosphorylation to construct the plasmid pLC0. The DNA fragment P8-F containing the P8 promoter [33] was obtained by PCR using primers KF147-P8F and KF147-P8R (see Additional file 1: Table S1) and genomic DNA of Lactococcus lactis subsp. lactis KF147 as template. The DNA fragment efALS-F was amplified from Enterococcus faecalis ATCC 29212 (purchased from German Collection of Microorganisms and Cell Cultures GmbH, DSM No.: 2570) with the primers $A L S-E F-C F 1$ and $A L S-E F-C R 1$ by PCR (Additional file 1: Table S1). The DNA fragment $w x A L S-F$ was obtained by PCR, using the primer pair WX02-ALS-F/WX02-ALS-R (see Additional file 1: Table S1) and synthetic DNA as template (see Additional file 1). The DNA fragment $l l A L S-F$ was amplified from genomic DNA of Lactococcus lactis MG1363 using primers $A L S-L l-C F 1$ and $A L S-L l-C R 1$ (see Additional file 1: Table S1). The fragments P8-F and efALS$\mathrm{F}$ were inserted the vector $p L C O-L$ simultaneously by using the In-Fusion ${ }^{\circledR}$ HD Cloning Kit (https://www. takarabio.com) to generate the plasmid pLC01. The plasmids pLC02 and pLC17 were constructed in the same way but with the fragments $w x A L S-F$ and $l l A L S$ $F$, respectively.

Fermentation for producing pyruvate and broth treatment Pyruvate was produced from glucose or lactose contained in Residual Whey Permeate (RWP) as described by Suo et al. (manuscript submitted) with minor modifications. Fermentations were carried out in Biostat A bioreactors equipped with 1 -L vessels. For glucose fermentations, M17 medium was used. The seed culture (20 ml) was inoculated $1 / 100$ from an overnight culture in a shake flask using M17 medium containing $1 \%(\mathrm{w} / \mathrm{v})$ glucose and incubated with strong shaking at $30{ }^{\circ} \mathrm{C}$ for $16 \mathrm{~h}$. Subsequently, the seed culture was used to inoculate $800 \mathrm{ml} \mathrm{M17-medium} \mathrm{1/100.} \mathrm{Initially,} \mathrm{5 \%} \mathrm{glucose}$ was added to the medium and another $2 \%$ was added subsequently when the sugar concentration decreased below 3\% (after approximately $24 \mathrm{~h}$ ). Temperature and $\mathrm{pH}$ were kept constant at $30^{\circ} \mathrm{C}$ and $\mathrm{pH} 7.0$, respectively. The fermenters were aerated using air at $1000 \mathrm{ccm} / \mathrm{min}$ and stirring at $500 \mathrm{rpm}$. Glucose was fully depleted after $72 \mathrm{~h}$ and the medium harvested. When fermenting RWP, the same conditions were applied. RWP was diluted twofold to lower lactose concentration to $5-6 \%$ lactose, and was supplemented with $2 \%$ yeast extract (autoclaved separately). The fermentation was terminated after $48 \mathrm{~h}$ when lactose was depleted. Cells were removed from the fermentation broth by centrifugation $(10,000 \times g, 10 \mathrm{~min})$ and the $\mathrm{pH}$ of the resulting pyruvate-rich broth was adjusted to 5.5 using $1 \mathrm{M} \mathrm{HCl}$. 
Whole-cell biocatalyst preparation and biotransformation Small-scale reactions were carried out in $1 \mathrm{ml}$ scale using $1.5 \mathrm{ml}$ reaction tubes. Cells were grown in GM17 broth, containing tetracycline $(5 \mu \mathrm{g} / \mathrm{ml})$ when required, at $30{ }^{\circ} \mathrm{C}$ for $16 \mathrm{~h}$ overnight. The cells were harvested by centrifugation, washed once with cold Tris/ $\mathrm{NaCl}$-buffer (100 mM/150 mM, pH 6.5) and suspended in $\mathrm{H}_{2} \mathrm{O}$. The optical density $\left(\mathrm{OD}_{600}\right)$ was determined in duplicate and set to approximately $\mathrm{OD}_{600}=50$. During harvesting, cells were kept on ice. For starting the reactions, the cell suspensions were centrifuged and cells were resuspended in solutions containing pyruvate, either pure or contained in fermentation broth. The cell suspensions were incubated at the set-point temperatures in ThermoMixer with shaking. Negative control reactions were carried out in the same way but without any pyruvate.

For laboratory scale biotransformations, cells were grown anaerobically in $5 \mathrm{ml}$ GM17 broth at $30{ }^{\circ} \mathrm{C}$ for overnight. Subsequently, $500 \mathrm{ml}$ cultures in 1-L shake flasks were inoculated 1:1000. After grown for 14-16 h at $30{ }^{\circ} \mathrm{C}$ with shaking, cells were harvested as described above. Laboratory scale biotransformation were carried out in 1-L fermenters (Sartorius "Biostat-A" equipped with a "UniVessel Glass"). The reaction vessel was filled with $350 \mathrm{ml} 0.5 \mathrm{M}$ pyruvate solution or pyruvate containing fermentation broth. Before adding the cells, the reaction solution was flushed with $\mathrm{N}_{2}$ and cooled to $20{ }^{\circ} \mathrm{C}$. During the reaction, the $\mathrm{pH}$ was kept constant at 5.5 using $1 \mathrm{M} \mathrm{HCl}$. The acid consumption was recorded during the process (see Additional file 1: Figure S5) and samples were taken regularly for analysis. Dilution factors were applied to the results.

\section{Optimization of the reaction conditions}

Determination of the optimal $\mathrm{pH}$ for the reaction and comparison of different whole-cell biocatalysts was carried out using an iCinac instrument. For this purpose, $10 \mathrm{ml}$ of non-buffered pyruvate solution $(0.5 \mathrm{M})$ was prepared and the $\mathrm{pH}$ was set to 4.6, which is the lowest $\mathrm{pH}$ allowing $\alpha$-acetolactate synthase reaction. This solution was equipped with a $\mathrm{pH}$-electrode and after stabilization of $\mathrm{pH}$ and temperature cells were added to reach a final $\mathrm{OD}_{600} 2.5$. Immediately after addition of the cells, the $\mathrm{pH}$ recording was started. The resulting $\mathrm{pH}$-shift allowed the determination of the optimal $\mathrm{pH}$ for the reaction and comparison of different whole-cell biocatalysts.

For determining the optimal temperature for the biotransformations, $\alpha$-acetolactate stability was investigated. In this case $\alpha$-acetolactate was obtained by hydrolyzing ethyl-2-acetoxy-2-methylacetoacetate using an equimolar amount of $\mathrm{NaOH}$ and incubating at room temperature for $1 \mathrm{~h}$. The resulting hydrolysate was added to a solution containing $500 \mathrm{mM}$ pyruvate and $100 \mathrm{mM}$ citrate at $\mathrm{pH} 5.5$. The mixture was incubated at $20^{\circ} \mathrm{C}, 30^{\circ} \mathrm{C}$, $40{ }^{\circ} \mathrm{C}$ and $50{ }^{\circ} \mathrm{C}$, and the concentration of $\alpha$-acetolactate and side products was followed over time.

\section{Analytical methods}

Cell growth was monitored by measuring the optical density at $600 \mathrm{~nm}\left(\mathrm{OD}_{600}\right)$. Determination of glucose, lactose, pyruvate, lactate and acetoin was carried out by HPLC equipped with the Aminex HPX-87H column (Bio-Rad, Hercules, USA) and RI detector. Additionally, pyruvate was determined by UV detector at $210 \mathrm{~nm}$. The column oven temperature was set at $60{ }^{\circ} \mathrm{C}$ and $5 \mathrm{mM} \mathrm{H}_{2} \mathrm{SO}_{4}$ was used as the mobile phase at a flow rate of $0.5 \mathrm{ml} / \mathrm{min}$. The $\alpha$-acetolactate was quantified after conversion to acetoin, which was subsequently analyzed by HPLC, whereby the conditions for the conversion were adapted from [10]. Briefly, the samples were diluted three-fold in water (reference sample) and threefold in $0.5 \mathrm{M} \mathrm{HCl}$ (treated sample). Subsequently, the treated sample was incubated $30 \mathrm{~min}$ at $44{ }^{\circ} \mathrm{C}$ to allow decarboxylation of $\alpha$-acetolactate to acetoin, while the reference sample was stored at $4{ }^{\circ} \mathrm{C}$ in order to prevent this reaction. Finally, both samples were analyzed using HPLC. The $\alpha$-acetolactate concentration was obtained by subtracting the acetoin concentration of the reference sample from the acetoin concentration of the treated sample and dividing by the factor $0.62[10,34]$.

Alternatively, acetoin and $\alpha$-acetolactate concentrations were determined using a colorimetric assay. $50 \mu \mathrm{l}$ of reaction mixtures were added in a 96-well micro-titerplate (MTP). $5 \mu \mathrm{l} 2 \mathrm{M} \mathrm{H}_{2} \mathrm{SO}_{4}$ were added to the mixtures for decarboxylation of $\alpha$-acetolactate to acetoin, which was completed by incubation for $15 \mathrm{~min}$ at $60{ }^{\circ} \mathrm{C}$. Subsequently, $45 \mu \mathrm{l} 0.5 \%$ creatine in $\mathrm{H}_{2} \mathrm{O}$ and $45 \mu \mathrm{l} 5 \%$ 1-Naphthol in $2 \mathrm{M} \mathrm{NaOH}$ were added and mixed by pipetting several times. Color formation was completed by first incubating for $15 \mathrm{~min}$ at $60{ }^{\circ} \mathrm{C}$ and then $15 \mathrm{~min}$ at $20^{\circ} \mathrm{C}$. Finally, the absorbance at $530 \mathrm{~nm}$ was measured using a plate reader. As a blank value, negative control reactions without pyruvate were used. A standard curve was measured each time using acetoin $(0-1 \mathrm{mM})$ dissolved in the respective reaction solution. The procedures above are based on the method developed by W. Westerfeld for detecting acetoin and were adapted and modified as previously described $[26,35,36]$.

\section{Supplementary information}

Supplementary information accompanies this paper at https://doi. org/10.1186/s12934-019-1271-1.

Additional file 1: Table S1. Primers and gBlock sequence (bl-ALS). Table S2. Catalytic properties of used ALS enzymes. Figures S1-S9. Supplementary results. 


\section{Acknowledgements \\ Not applicable.}

\section{Authors' contributions}

$R D$, JL, CS and PRJ designed and conceived the project. RD and LC performed all the experiments. All the authors analyzed the results, prepared the manuscript. All authors read and approved the final manuscript.

\section{Funding}

This work is funded by Danish Dairy Research Foundation \& Innovation Fund Denmark (Case no. 6150-00036B).

Availability of data and materials

All data generated in this study are included in this article.

\section{Ethics approval and consent to participate}

Not applicable.

\section{Consent for publication}

All the authors agree to submit this original research work to Microbial cell factories. The article has not been published or submitted in any other peerreviewed journals.

\section{Competing interests}

The authors declare that they have no competing interests.

Received: 23 August 2019 Accepted: 14 December 2019 Published online: 29 December 2019

\section{References}

1. Clark S, Winter CK. Diacetyl in foods: a review of safety and sensory characteristics. Compr Rev Food Sci Food Saf. 2015;14(5):634-43. https://doi. org/10.1111/1541-4337.12150.

2. Wijaya I, Rankin SA. Diacetyl levels and volatile profiles of commercial starter distillates and selected dairy foods. J Dairy Sci. 2012;95(3):1128-39. https://doi.org/10.3168/jds.2011-4834

3. Zeitsch KJ. 16. Diacetyl and 2,3-pentanedione. In: Zeitsch KJ, editor. Sugar Series. 2000. p. 120-49. https://doi.org/10.1016/s0167-7675(00)80016-0.

4. de Man JC. The formation of diacetyl and acetoin from a-acetolactic acid. Recl des Trav Chim des Pays-Bas. 1959:78(7):480-6. https://doi. org/10.1002/recl.19590780703.

5. de Medina Figueroa R, Oliver G, de Benito Cárdenas IL. Influence of temperature on flavour compound production from citrate by Lactobacillus rhamnosus ATCC 7469. Microbiol Res. 2001;155(4):257-62. https://doi. org/10.1016/s0944-5013(01)80002-1.

6. Branen AL, Keenan TW. Diacetyl and acetoin production by Lactobacillus casei. Appl Microbiol. 1971;22(4):517-21.

7. Laëtitia G, Pascal D, Yann D. The citrate metabolism in homo- and heterofermentative $L A B$ : a selective means of becoming dominant over other microorganisms in complex ecosystems. Food Nutr Sci. 2014;5(10):95369. https://doi.org/10.4236/fns.2014.510106.

8. Starrenburg MJC, Hugenholtz J. Citrate fermentation by Lactococcus and Leuconostoc spp. Appl Environ Microbiol. 1991:57(12):3535-40.

9. Verhue WM, Tjan FSB. Study of the citrate metabolism of Lactococcus lactis subsp. lactis biovar diacetylactis by means of 13c nuclear magnetic resonance. Appl Environ Microbiol. 1991;57(11):3371-7.

10. Jordan KN, Cogan TM. Production of acetolactate by Streptococcus diacetylactis and Leuconostoc spp. J Dairy Res. 1988;55(2):227-38. https://doi. org/10.1017/S0022029900026054.

11. Ronfags E, Stien G, Germain P, Marc I. Kinetic study of the chemical reactivity of a-acetolactate as a function of $\mathrm{pH}$ in water, and in fresh and fermented culture media used for Lactococcus lactis spp. lactis bv diacetylactis. Biotechnol Lett. 1996;18(7):747-52.

12. Liu J, Chan SHJ, Brock-Nannestad T, Chen J, Lee SY, Solem C, Jensen PR. Combining metabolic engineering and biocompatible chemistry for high-yield production of homo-diacetyl and homo-(S, S)-2,3-butanediol. Metab Eng. 2016;36:57-67. https://doi.org/10.1016/j.ymben.2016.02.008.
13. Seitz EW, Elliker P, Day EA, Sandine W. Studies on factors affecting diacetyl production by Streptococcus diacetylactis. J Dairy Sci. 1961:44(6):1159.

14. Hugenholtz J, Kleerebezem M, Starrenburg M, Delcour J, De Vos W, Hols P. Lactococcus lactis as a cell factory for high-level diacetyl production. Appl Environ Microbiol. 2000;66(9):4112-4. https://doi. org/10.1128/AEM.66.9.4112-4114.2000.

15. Guo T, Kong J, Zhang L, Zhang C, Hu S. Fine tuning of the lactate and diacetyl production through promoter engineering in Lactococcus lactis. PLoS One. 2012. https://doi.org/10.1371/journal.pone.0036296.

16. Goupil N, Corthier G, Ehrlich SD, Renault P. Imbalance of leucine flux in Lactococcus lactis and its use for the isolation of diacetyl-overproducing strains. Appl Environ Microbiol. 1996;62(7):2636-40.

17. Aymes F, Monnet C, Corrieu G. Effect of a-acetolactate decarboxylase inactivation on a-acetolactate and diacetyl production by Lactococcus lactis subsp. lactis biovar diacetylactis. J Biosci Bioeng. 1999:87:87-92.

18. Monnet C, Aymes F, Corrieu G. Diacetyl and a-acetolactate overproduction by Lactococcus lactis subsp. lactis biovar diacetylactis mutants that are deficient in a-acetolactate decarboxylase and have a low lactate dehydrogenase activity. Appl Environ Microbiol. 2000;66(12):5518-20. https://doi.org/10.1128/aem.66.12.5518-5520.2000.

19. Monnet C, Schmitt P, Divies C. Development and use of a screening procedure for production of a-acetolactate by Lactococcus lactis subsp. lactis biovar diacetylactis strains. Appl Environ Microbiol. 1997;63(2):793-5.

20. Jay JM. Antimicrobial properties of diacetyl. Appl Environ Microbiol. 1982:44(3):525-32.

21. Verhue WMM, Tjan SB, Verrips CT, van Schie BJ. Process for preparing an aroma product containing a-acetolactic acid. European Patent Application; EP0483888A2, 1991. p. 1-14.

22. Marugg JD, Toonen MY, Verhue WMM, Verrips CT. Process for the preparation of a-acetolactic acid. European Patent Application; EP0500188A2, 1992. p. 1-23.

23. Liu J, Wang Z, Kandasamy V, Lee SY, Solem C, Jensen PR. Harnessing the respiration machinery for high-yield production of chemicals in metabolically engineered Lactococcus lactis. Metab Eng. 2017;44:22-9. https://doi. org/10.1016/j.ymben.2017.09.001.

24. De Felipe FL, Starrenburg M, Hugenholtz J. The role of NADH-oxidation in acetoin and diacetyl production from glucose in Lactococcus lactis subsp. lactis MG1363. FEMS Microbiol Lett. 1997;156:15-9. https://doi. org/10.1016/s0378-1097(97)00394-7.

25. Huo Y, Zhan Y, Wang Q, Li S, Yang S, Nomura CT, Wang C, Chen S. Acetolactate synthase (AlsS) in Bacillus licheniformis WX-02: enzymatic properties and efficient functions for acetoin/butanediol and L-valine biosynthesis. Bioprocess Biosyst Eng. 2018;41(1):87-96. https://doi. org/10.1007/s00449-017-1847-2.

26. Lee SC, Kim J, La IJ, Kim SK, Yoon MY. Characterization of recombinant FAD-independent catabolic acetolactate synthase from Enterococcus faecalis V583. Enzyme Microb Technol. 2013;52(1):54-9. https://doi. org/10.1016/j.enzmictec.2012.10.006.

27. Zhao L, Bao Y, Wang J, Liu B, An L. Optimization and mechanism of diacetyl accumulation by Enterobacter aerogenes mutant UV-3. World J Microbiol Biotechnol. 2009;25(1):57-64. https://doi.org/10.1007/s1127 4-008-9862-8.

28. Somkuti GA, Dominiecki ME, Steinberg DH. Permeabilization of Streptococcus thermophilus and Lactobacillus delbrueckii subsp. bulgaricus with Ethanol. Curr Microbiol. 1998;36(4):202-6. https://doi.org/10.1007/s0028 49900294.

29. Shin KC, Sim DH, Seo MJ, Oh DK. Increased production of food-grade D-tagatose from D-galactose by permeabilized and immobilized cells of Corynebacterium glutamicum, a GRAS host, expressing D-galactose isomerase from Geobacillus thermodenitrificans. J Agric Food Chem. 2016;64(43):8146-53. https://doi.org/10.1021/acs.jafc.6b03588.

30. Gasson MJ. Plasmid complements of Streptococcus lactis NCDO 712 and other lactic streptococci after protoplast-induced curing. J Bacteriol. 1983:154(1):1-9.

31. Solem C, Defoor E, Jensen PR, Martinussen J. Plasmid pCS1966, a new selection/counterselection tool for lactic acid bacterium strain construction based on the oroP gene, encoding an orotate transporter from Lactococcus lactis. Appl Environ Microbiol. 2008;74(15):4772-5. https:// doi.org/10.1128/AEM.00134-08. 
32. Solem C, Dehli T, Jensen PR. Rewiring Lactococcus lactis for ethanol production. Appl Environ Microbiol. 2013;79(8):2512-8. https://doi. org/10.1128/AEM.03623-12.

33. Zhu D, Liu F, Xu H, Bai Y, Zhang X, Saris PEJ, Qiao M. Isolation of strong constitutive promoters from Lactococcus lactis subsp. lactis N8. FEMS Microbiol Lett. 2015;362(16):1-6. https://doi.org/10.1093/femsle/fnv107.

34. Benson KH, Godon JJ, Renault P, Griffin HG, Gasson MJ. Effect of ilvBNencoded a-acetolactate synthase expression on diacetyl production in Lactococcus lactis. Appl Microbiol Biotechnol. 1996;45(1-2):107-11. https ://doi.org/10.1007/s002530050656.

35. Nguyen DMN, Lipscomb GL, Schut GJ, Vaccaro BJ, Basen M, Kelly RM, Adams MWW. Temperature-dependent acetoin production by
Pyrococcus furiosus is catalyzed by a biosynthetic acetolactate synthase and its deletion improves ethanol production. Metab Eng. 2016;34:71-9. https://doi.org/10.1016/j.ymben.2015.12.006.

36. Westerfeldt WW. A colorimetric determination of blood acetoin. J Biol Chem. 1945;161:495-502

\section{Publisher's Note}

Springer Nature remains neutral with regard to jurisdictional claims in published maps and institutional affiliations.
Ready to submit your research? Choose BMC and benefit from:

- fast, convenient online submission

- thorough peer review by experienced researchers in your field

- rapid publication on acceptance

- support for research data, including large and complex data types

- gold Open Access which fosters wider collaboration and increased citations

- maximum visibility for your research: over $100 \mathrm{M}$ website views per year

At BMC, research is always in progress.

Learn more biomedcentral.com/submissions 